\title{
Myxococcus xanthus, a Gram-negative bacterium, contains a transmembrane protein serine/threonine kinase that blocks the secretion of $\beta$-lactamase by phosphorylation
}

\author{
Hiroshi Udo, Jose Munoz-Dorado, ${ }^{1}$ Masayori Inouye, and Sumiko Inouye ${ }^{2}$ \\ Department of Biochemistry, Robert Wood Johnson Medical School, Piscataway, New Jersey 08854 USA
}

\begin{abstract}
A gene, pkn2, encoding a Myxococcus xanthus protein with significant similarities to eukaryotic protein serine/threonine kinases, was cloned using the polymerase chain reaction. The open reading frame for the protein, beginning with a GUG initiation codon, consists of 830 amino acids. The amino-terminal 279 residues show $37 \%$ identity to catalytic domain of $\mathrm{Pkn} 1$, another protein serine/threonine kinase expressed during the development at the onset of sporulation. The catalytic domain of $\mathbf{P k n} 2$ contains $27 \%$ and $25 \%$ identity to rat $\mathrm{Ca}^{2+} /$ calmodulin-dependent protein kinase and Bos taurus rhodopsin kinase, respectively. In the middle of the carboxy-terminal regulatory domain, there is a typical transmembrane domain consisting of 18 hydrophobic residues. The gene product, Pkn2, produced in Escherichia coli under a $T 7$ promoter was phosphorylated at both serine and threonine residues. TEM- $\beta$-lactamase produced in $E$. coli was found to serve as an effective substrate for Pkn2, phosphorylated only at threonine residues, shifting its apparent molecular mass from 29 to $44 \mathrm{kD}$. The phosphorylated $\beta$-lactamase was unable to be secreted into the periplasmic space and localized in the cytoplasmic and membrane fractions. Analysis of phoA fusions with pkn2 demonstrated that Pkn2 is a transmembrane protein with the kinase domain in the cytoplasm and the 207-residue carboxy-terminal domain outside the cytoplasmic membrane. Disruption of pkn2 showed no effect on vegetative growth but reduced the yield of myxospores by $30 \%-50 \%$. On the basis of the present results, we propose that $\mathrm{Pkn} 2$ is a transmembrane protein serine/threonine kinase that regulates the activity of endogenous $\beta$-lactamase or related enzymes in response to an external signal yet to be identified.
\end{abstract}

[Key Words: Protein serine/threonine kinase; myxobacteria; transmembrane protein kinase; $\beta$-lactamase]

Received January 25, 1995; revised version accepted March 9, 1995.

Protein kinase cascades play major roles in intracellular signal transduction regulating various cellular functions in both prokaryotes and eukaryotes. In prokaryotes, protein histidine kinases are known to be the key enzymes for the cascades, and it has been believed for a long time that protein serine/threonine kinases do not exist in prokaryotes. These kinases, together with protein tyrosine kinases, are essential in signal transduction in eukaryotes. However, recently, the existence of such eukaryotic-like protein serine/threonine kinases in Myхоcoccus xanthus, a Gram-negative bacterium, has been demonstrated (Munoz-Dorado et al. 1991; Zhang et al. 1992). M. xanthus living in the soil shows rather spectacular morphogenesis, including multicellular fruiting body formation upon nutrient starvation (for review, see

\footnotetext{
${ }^{1}$ Present address: University of Granada, Department of Microbiology, Faculty of Sciences, Granada 18071 Spain.

${ }^{2}$ Corresponding author.
}

Shimkets 1990). Within the fruiting body, a significant population of rod-shaped vegetative cells differentiate into spherical heat-resistant spores. It is believed that $M$. xanthus responds to a large number of signals in its natural habitat to regulate its cell-cell communication, gliding motility, aggregation, fruiting body formation, and differentiation to myxospores. The first prokaryotic protein serine/threonine kinase, $\mathrm{Pknl}$, has been characterized extensively and shown to be required for normal development of M. xanthus (Munoz-Dorado et al. 1991).

In this study we describe another protein serine/threonine kinase from $M$. xanthus, designated $\mathrm{Pkn} 2$. In contrast to Pkn1, Pkn2 was found to be a transmembrane protein kinase, which was able to effectively phosphorylate threonine residues of TEM- $\beta$-lactamase to block its secretion across the membrane. We propose that $\mathrm{Pkn} 2$ senses an external signal yet to be identified to regulate the activity of $\beta$-lactamase and/or related enzymes by phosphorylation. This is the first demonstration that a 
prokaryotic organism contains a transmembrane protein serine/threonine kinase. The significance of the role of $\mathrm{Pkn} 2$ in $M$. xanthus is discussed.

\section{Results}

Identification and cloning of the $\mathrm{pkn} 2$ gene

From the polymerase chain reaction (PCR) performed on the $M$. xanthus chromosomal DNA, using degenerate oligonucleotides designed according to the consensus sequences of catalytic subdomains VI and VIII of eukaryotic protein kinases as primers, two different DNA sequences were obtained, PCRPKl and PCRPK2 (MunozDorado et al. 1991). The sequence of PCRPK2 is shown in Figure 1A. PCRPK2 has a length of 173 bp and contains the consensus sequence DFG characteristic of subdomain VII in the same reading frame as subdomains VI and VIII of eukaryotic protein kinases (Hanks et al. 1988). This indicates that $M$. xanthus contains another eukaryotic-like protein kinase in addition to $\mathrm{Pknl}(\mathrm{Mu}-$ noz-Dorado et al. 1991). PCRPK2 seems to be quite different from PCRPK1 (Munoz-Dorado et al. 1991). It has one extra codon over PCRPKl, and more significantly, the identity of the deduced amino acid sequences between the two PCR products is only $26 \%$, excluding the sequences of the primers used in the reaction.

Using PCRPK2 as a probe, we attempted to isolate the entire gene corresponding to the PCRPK2 sequence. Southern blot hybridization analysis of $M$. xanthus chromosomal DNA digestions revealed that only one DNA fragment for each restriction enzyme digestion hybridized with the PCRPK2 probe (Fig. 1B). Positive clones were obtained from an $M$. xanthus genomic DNA library constructed in phage $\lambda$ with use of the same probe. Of 1632 phages screened, 2 were detected as positive and the DNA from one of them was purified as described in Materials and methods. After digestion of the phage DNA with Sall, a $4.8-\mathrm{kb}$ fragment was purified and cloned into pUC at the SalI site. The plasmid thus obtained was designated pIMPK2S. Because this fragment did not contain the initiation codon of the open reading frame (ORF), shown below, another DNA fragment was cloned from the same phage $\lambda$ DNA. A $2.5-\mathrm{kb}$ Xhol fragment was cloned into the pUX vector (Apelian and Inouye 1990) at the XhoI site, resulting in plasmid pIMPK2X. Using both pJMPK2S and pIMPK2X, a new construct designated pIMPK2HB was constructed, which contains the 7.3-kb Xhol $(\mathrm{a} /$-Sall(b) fragment encompassing the entire ORF. The physical map of the region containing the $p k n 2$ gene is shown in Figure 2.

\section{pkn2 encodes a putative protein serine/threonine kinase}

The entire sequence of the $2.5-\mathrm{kb}$ XhoI fragment of pIMPK2X and most of the sequence of the $4.8-\mathrm{kb}$ SalI fragment of pIMPK2S was determined by using the strategy described in Material and methods. The DNA sequence obtained, starting from the XhoI(a) site (Fig. 2) is shown in Figure 3. The relationship between the two fragments and the position of the pkn2 gene are shown in Figure 2. The ORF was in the same reading frame as that of PCRPK2 and contained the consensus sequences of the 11 subdomains (Fig. 3) defined for the catalytic domain of eukaryotic protein serine/threonine kinases (Hanks et al. 1988). There are no ATG codons upstream of the consensus sequence of subdomain I starting from base 421 . Instead, there are two GTG codons (positions 341-343 and 392-394). However, the codons used between the two GTG codons show a low $\mathrm{G}+\mathrm{C}$ usage at the third position $(10$ of $16 ; 62.5 \%)$ in contrast to a high $\mathrm{G}+\mathrm{C}$ usage of the codons used after the second GTG $(92.5 \%)$, a typical codon usage in $M$. xanthus (Inouye et al. 1989). Thus, the ORF for $p k n 2$ is tentatively assigned from the second GTG (base 392-394) to the TGA termination codon (base 2882-2884). A putative ribosomebinding site, AAGATG, can be identified 8 bases upstream of the initiation codon. The ORF should encode a protein ( $\mathrm{Pkn} 2$ ) of 830 amino acid residues, with a calculated molecular weight of 87,594 .

When the deduced amino acid sequence of $\mathrm{Pkn} 2$ was examined for sequence similarities with other proteins, it was found to contain the consensus catalytic domain of eukaryotic protein serine/threonine kinases from
A

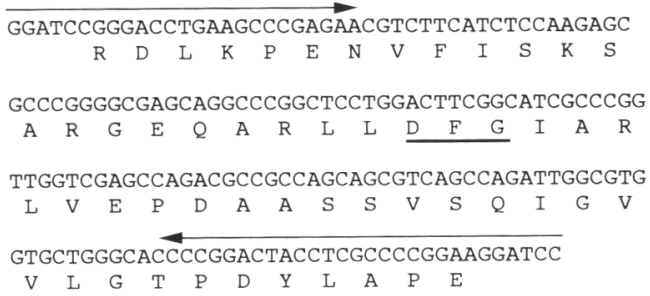

B

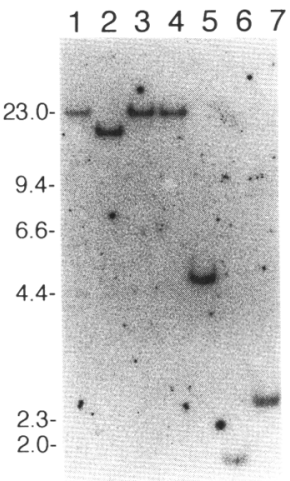

Figure 1. Identification of the $p k n 2$ gene. $(A)$ The sequence of PCRPK2. The sequences of the primers used for PCR are marked by long arrows, and the highly conserved sequence in the subdomain VII of eukaryotic protein kinases is underlined. $(B)$ Southern blot hybridization of the $M$. xanthus chromosomal DNA with the PCRPK2 probe. The digestions used were $B a m H I$, (lane 1); BamHI and EcoRI, (lane 2); BamHI and HindIII, (lane 3); BamHI and PstI, (lane 4); SalI (lane 5); Sall amd Xhol (lane 6); and XhoI (lane 7). The molecular mass standards are expressed in kilobases. 


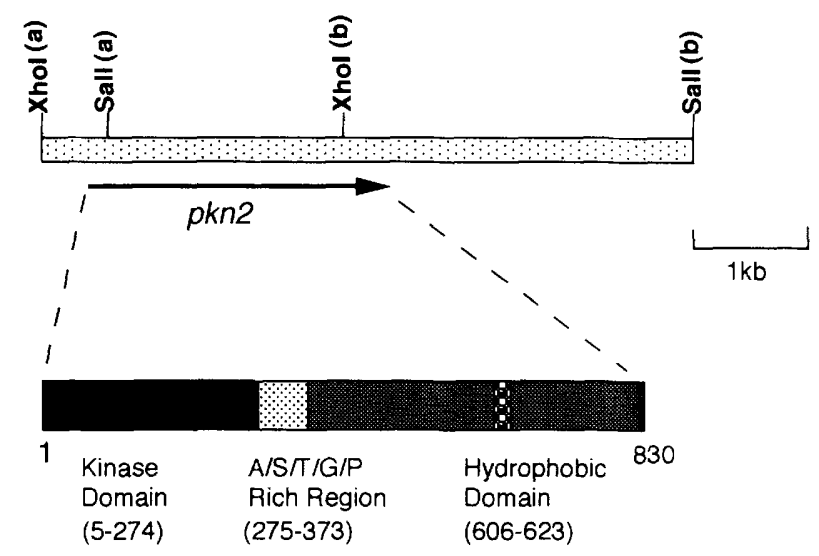

Figure 2. Restriction map of the $p k n 2$ locus and a domain structure of $P k n 2$. Numbers 1 and 830 represent the first and the last amino acid in the ORF, respectively.

amino acid residue $20-274$ (see Fig. 3 ) and the highest identity to the catalytic domain of $\mathrm{Pknl}(37 \%)$, a protein serine/threonine kinase of $M$. xanthus (Munoz-Dorado et al. 1991 \%. It also shows $27 \%$ identity with rat $\mathrm{Ca}^{2+} /$ calmodulin-dependent protein kinase (Lin et al. 1987) and $25 \%$ identity with Bos taurus rhodopsin kinase (Lorenz et al. 1991). After the catalytic domain, there is an unusual sequence of 99 amino acid residues (from residue 275 to 373 ) containing $20 \mathrm{Ser}, 10 \mathrm{Thr}, 23 \mathrm{Ala}, 17$ Gly, 10 Pro, and 0 charged residues (double-underlined in Fig. 3). These amino acid residues account for $81 \%$ of the sequence. This Ala/Ser/Thr/Gly/Pro-rich region is followed by a sequence of 467 amino acid residues (from residue 374 to 830 ), in the middle of which there is a hydrophobic stretch of 18 amino acid residues (from residue 606 to 623; boxed in Fig. 3). This hydrophobic sequence is flanked by Gln-Arg-Arg-Arg-Glu (total net charge is +2 ) at the amino-terminal side and by Ser-GlnArg-Asn-Asp (total net charge is 0 ) at the carboxy-terminal side within a sequence of 5 residues. This is a typical feature of a transmembrane domain (Gennity and Inouye 1991; Pugsley 1993; Gafvelin and von Heijne 1994; Kim et al. 1994) and predicts that $\mathrm{Pkn} 2$ is a transmembrane protein having the kinase domain in the cytoplasm and the carboxy-terminal domain downstream of the transmembrane domain outside the cytoplasmic membrane. Within the putative extracellular domain, the signature sequence PKDRLRAHY, known for mitochondrial energy transfer proteins (Klingenberg 1990; Nelson et al. 1993), was found from residue 722 to 730 (underlined in Fig. 3!.

\section{Pkn2 is a transmembrane protein}

The amino acid sequence deduced from the DNA sequence of $p k n 2$ showed the existence of a stretch of 18 hydrophobic amino acid residues (residues 606-623) preceded by positively charged residues in the middle of the regulatory domain, suggesting that this domain func- tions as an internal signal sequence (Kim et al. 1994). To demonstrate that this region can act as an internal signal sequence, fusion proteins, consisting of a fragment of $\mathrm{Pkn} 2$ and the E. coli alkaline phosphatase (PhoA), were constructed before and after the hydrophobic stretch as shown in Figure 4.

Two fusion proteins were designated $\mathrm{Pkn} 2-\mathrm{PhoA}-1$ and Pkn2-PhoA-2 (see Fig. 4). Their genes were constructed in pUC9 in such a way that their expression was under the control of the lac $Z$ promoter. In the presence of $1 \mathrm{mM}$ IPTG, Pkn2-PhoA-l showed very low PhoA activity (58 units) similar to the activity of the $p h o A^{-}$ host strain (16 units; see Fig. 4). However, when the hydrophobic stretch was added to the fusion protein, the phoA activity of the resulting protein, $\mathrm{Pkn} 2-\mathrm{PhoA}-2$ increased dramatically to 5067 units, which was similar to that of a phoA ${ }^{+}$control strain (4014 units; see Fig. 4).

Because PhoA is known to be active only when it is translocated across the membrane (Manoil and Beckwith 1985), the present results demonstrate that the hydrophobic domain corresponding to residues 606 to 623 functions as an internal signal sequence to translocate the PhoA domain fused downstream of the hydrophobic domain. Because the internal signal sequence appears to have no cleavage site at the carboxy-terminal end, the hydrophobic domain is likely to serve as a transmembrane domain. Therefore, the present results indicate that $\mathrm{Pkn} 2$ is a transmembrane protein consisting of the 207-residue carboxy-terminal domain in the periplasmic space and the 605-residue amino-terminal domain in the cytoplasm, where the kinase domain exists.

\section{Expression of $\mathrm{pkn} 2$ in $\mathrm{E}$. coli}

To characterize Pkn2, the $p k n 2$ gene was expressed in $E$. coli using a T7 RNA polymerase system. The $p k n 2$ gene was cloned under a T7 promoter in plasmid pET1la as described in Material and methods. In this construction, the GTG initiation codon for $p k n 2$ was substituted with an ATG codon. The plasmid thus obtained was designated $\mathrm{pET} 11 / p k n 2$. After transformation of $E$. coli BL21(DE3) with this plasmid, the expression of the pkn2 gene was induced with IPTG, and the proteins were labeled with $\operatorname{Tran}^{35} \mathrm{~S}$-label in the presence of rifampicin. As shown in Figure 5A, four new bands were induced in the presence of IPTG. As described later, band a was identified as $\mathrm{Pkn} 2$. Its apparent molecular mass $(110 \mathrm{kD})$ was higher than its expected molecular mass $(88 \mathrm{kD})$. This abnormal migration in a SDS-polyacrylamide gel is considered to be the result of phosphorylation of the product as observed for $\mathrm{Pknl}$ (Munoz-Dorado et al. 1991). The apparent molecular masses of bands b, c, and $\mathrm{d}$ were 44,31 , and $29 \mathrm{kD}$, respectively, and all of them were found to be derived from the bla gene in the pET1la vector used as described later.

Next, we investigated phosphorylation of Pkn2 using the method applied for Pknl (Munoz-Dorado et al. 1991). E. coli cells harboring $\mathrm{pET} 11 / \mathrm{pkn} 2$ were labeled with inorganic ${ }^{32} \mathrm{P}$ after induction with IPTG as described in 


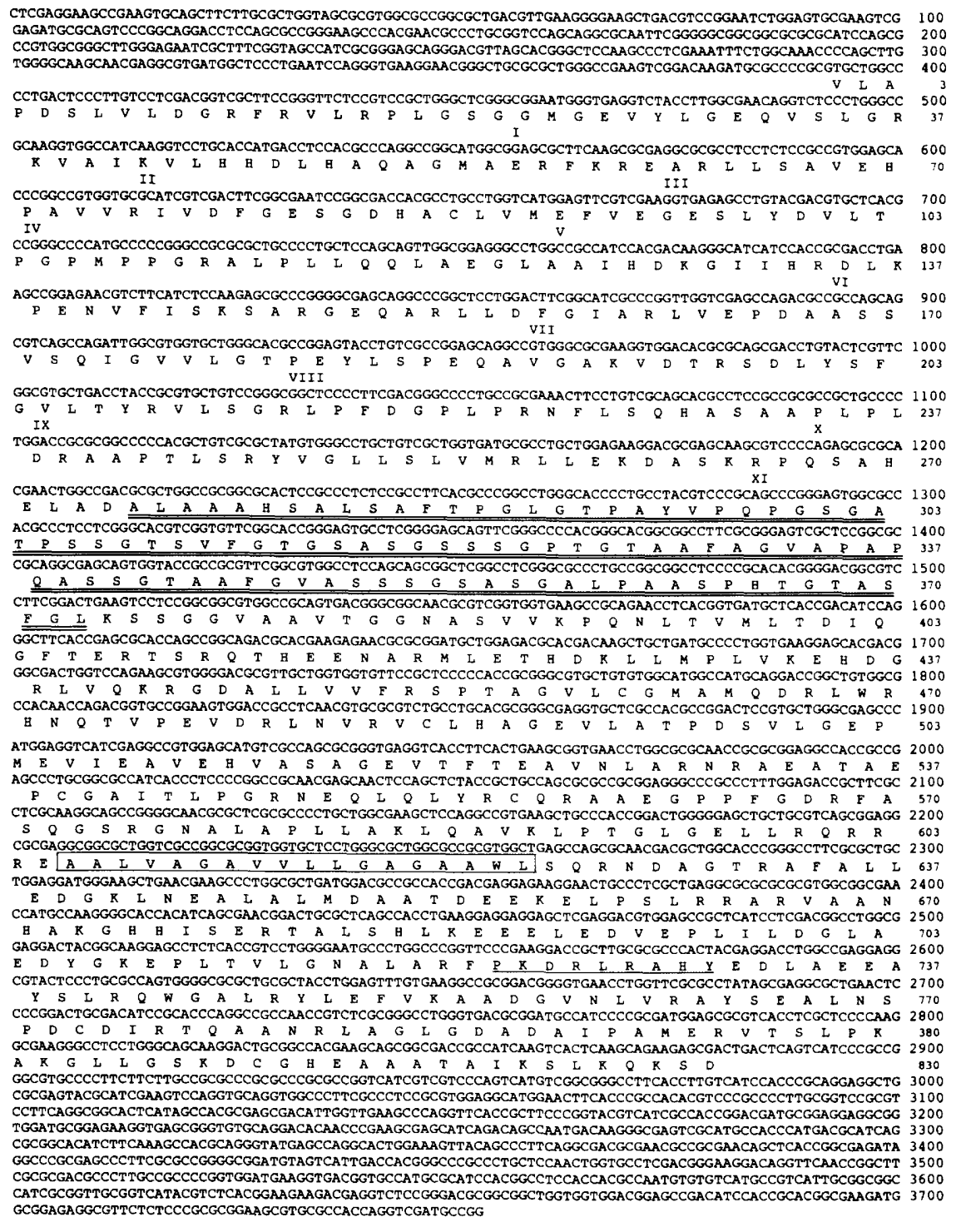

Figure 3. DNA sequence of 3753 bases encompassing pkn2 (GenBank/EMBL accession no. M94857) and the deduced amino acid sequence of $\mathrm{Pkn} 2$. Roman numerals represent conserved subdomains in the catalytic domain of kinases. The Ala/ Ser/Thr/Gly/Pro-rich region is doubly underlined. The sequence homologous to $\mathrm{mi}$ tochondrial energy transfer protein is underlined. The hydrophobic stretch is boxed.

Materials and methods. After a 3-hr induction, inclusion bodies were isolated and analyzed by SDS-PAGE. As shown in Figure 5B, of four bands $(a, b, c$, and d) only bands a and $b$ were labeled with ${ }^{32} \mathrm{P}$ (lane 2). To identify amino acid residues phosphorylated in these bands, they were extracted from the gel and hydrolyzed in $6 \mathrm{~N} \mathrm{HCl}$. The hydrolysates were separated by two-dimensional thin layer chromatography. The results are shown in Figure 5, C and D. Pkn2 (band a) was phosphorylated at both serine and threonine residues (Fig. $5 \mathrm{C}$ ), whereas the band $\mathrm{b}$ protein was mainly phosphorylated at threonine residues (Fig. 5D).

\section{Characterization of bands $b, c$, and $d$}

In addition to band $a$, the induction of bands $b$, $c$, and $d$ was puzzling. To determine whether these bands were derived from the pkn2 gene, we examined the precursor- product relationship between these bands. For this purpose, the cells harboring $\mathrm{pET} 11 / p k n 2$ were pulse-labeled for $5 \mathrm{~min}$ with $\operatorname{Tran}^{35} \mathrm{~S}$-label after induction with IPTG for $1 \mathrm{hr}$ and chased for 7.5, 15,30, and $60 \mathrm{~min}$. As shown in Figure 6, $\mathrm{Pkn} 2$ (indicated with arrow a) was detected with a molecular mass of $106 \mathrm{kD}$ during the 5-min pulse (lane 1). When chased, the position of Pkn2 gradually shifted to higher molecular mass, which was probably caused by continuous phosphorylation of $\mathrm{Pkn} 2$. In addition to band $a$, bands $b, c$, and d of 44,31 , and 29 $\mathrm{kD}$, respectively were pulse-labeled with $\operatorname{Tran}^{35} \mathrm{~S}$-label. The intensity of band $c$ decreased with a concomitant increase of the intensity of band $b$ during the chase period. These results suggest that band $\mathrm{c}$ at $31 \mathrm{kD}$ was chased into band $b$ at $44 \mathrm{kD}$, probably because of the post-translational modification of band $c$. Band $b$ is unlikely to be derived from $\mathrm{Pkn} 2$ (band a), because the intensity of band a remained constant throughout the chase period tested (Fig. 6). 


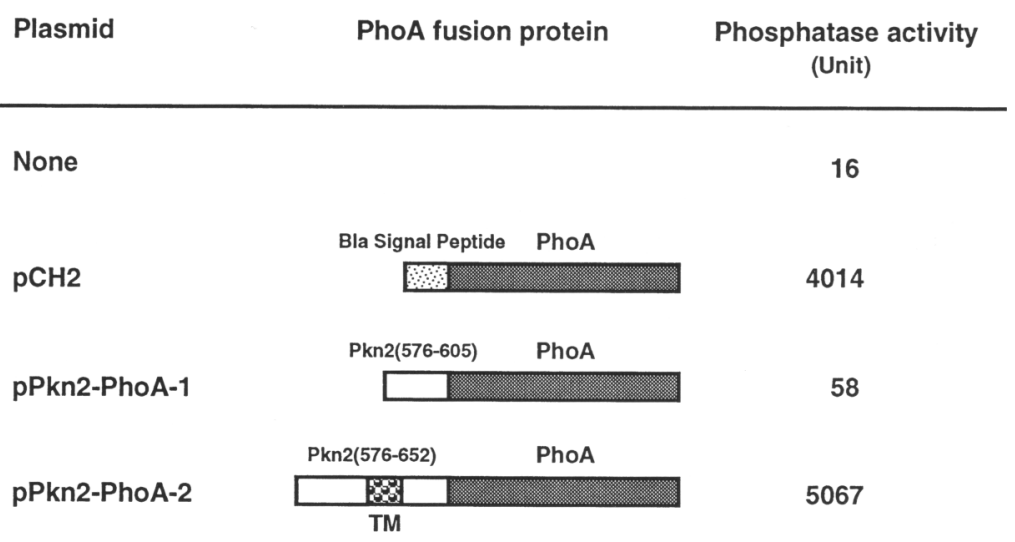

\section{Deletion analysis of pkn2 in $\mathrm{E}$. coli}

To confirm further that band a is the pkn2 product, various deletion mutations of the pkn2 gene were constructed, as described in Materials and methods, using the unique restriction enzyme sites in the gene [SacII (1221-1226), KpnI (1415-1420), MluI (1548-1553), NcoI (1899-1904), and XhoI (2462-2467; see Fig. 3)] as shown in Figure 7A. The deletion constructs were expressed under the control of the T7 promoter in pET1la. The mutation designated $\Delta \mathrm{Kn}$ was constructed by introduc- ing an NdeI site at Met-398 (see Fig. 3) followed by cloning the resulting $3.5-\mathrm{kb}$ NdeI-BamHI fragment into pETlla at its NdeI and BamHI sites. Therefore, the resulting plasmid, designated $\mathrm{p} \Delta \mathrm{Kn}$, encodes a carboxy-terminal fragment of $\mathrm{Pkn} 2$ consisting of 433 amino acid residues, which lacks the entire kinase domain.

The cells harboring $\mathrm{pET} 11 / \mathrm{pkn} 2$ and the deletion constructs were labeled with Tran ${ }^{35} \mathrm{~S}$-label for $30 \mathrm{~min}$ with or without IPTG induction in the presence of rifampicin. The products were then analyzed by SDS-PAGE as shown in Figure 7B. In the case of pET11/pkn2, Pkn2
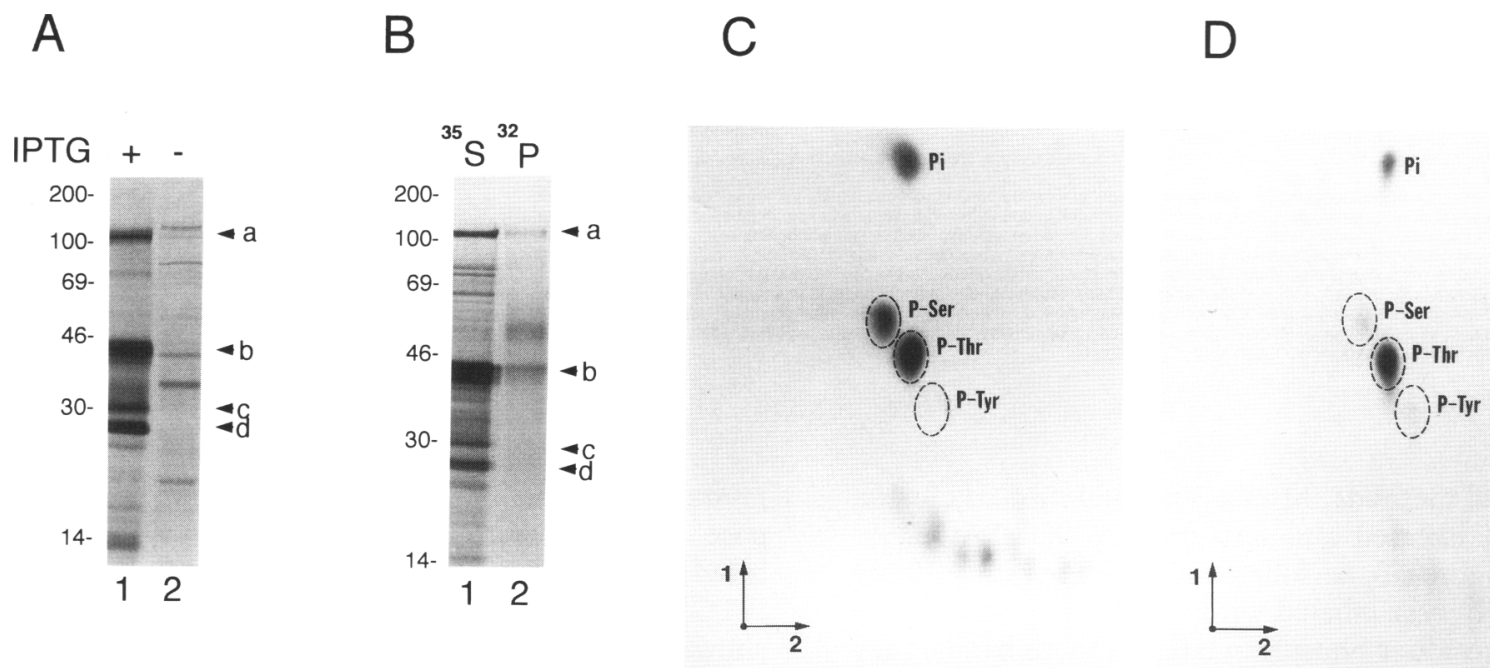

Figure 5. Expression of $\mathrm{Pkn} 2$ and identification of phosphorylated amino acid residues. $(A \mid$ Expression of $p k n 2$ under the T7 promoter in E. coli BL21 (DE3). Cells harboring pET/pkn2 were incubated in the presence (lane 1) or the absence (lane 2) of $1 \mathrm{mM}$ IPTG, and then labeled with Tran ${ }^{35} \mathrm{~S}$-label in the presence of rifampicin $(150 \mu \mathrm{g} / \mathrm{ml})$ as described in Materials and methods. Total cellular proteins were subjected to SDS-PAGE. Proteins were blotted on an immobilon-P membrane, which was then exposed to X-ray film. Letters with an arrow indicate the positions of $\mathrm{Pkn} 2$ (band $a$ ) and other products from pET1l/pkn2 (bands $b, c$, and $d$ ) (see text). Bars with numbers at left indicate the positions of molecular mass markers $(\mathrm{kD}) .(B)$ Phosphorylation of the products from pET11/pkn2. Cells harboring $\mathrm{pET} 11 / p k n 2$ were labeled with either $\operatorname{Tran}^{35} \mathrm{~S}$-label (lane 1) or ortho- ${ }^{32} \mathrm{P}$ (lane 2) after 2-hr induction with IPTG in the presence of rifampicin as described in Materials and methods. (Lane 1) SDS-gel analysis of total cellular proteins labeled with Tran ${ }^{35} \mathrm{~S}$-label; (lane 2) SDS-gel analysis of inclusion bodies labeled with ortho- ${ }^{32} \mathrm{P}$. Inclusion bodies were isolated by a low centrifugation after sonification as described in Materials and methods. SDS-PAGE was carried out as in $A .|C, D|$ Phosphoamino acid analysis of Pkn2 and band $b$ in lane 2 (in $B$ ) (described in Materials and methods). The positions of the nonradioactive phosphoamino acid standards [(P-Ser) phosphoserine; (P-Thr) phosphothreonine; (P-Tyr) phosphotyrosine) identified by ninhydrin and the position of inorganic phosphate (Pi) are shown by broken lines. The first and second dimensions used for the separation of the phosphoamino acids are indicated by numbers 1 and 2, respectively. The origin is indicated by a dot at the intersection of arrows 1 and 2. 


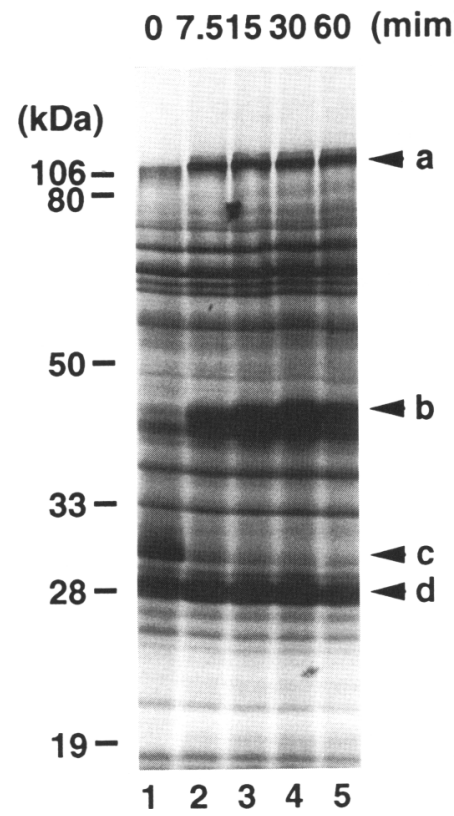

Figure 6. Pulse-chase experiment of E. coli BL2l (DE3) harboring $\mathrm{pET} 11 / p k n 2$. Cells harboring $\mathrm{pET} 11 / p k n 2$ were labeled with $\operatorname{Tran}^{35} \mathrm{~S}$-label for $5 \mathrm{~min}$ in the presence of $1 \mathrm{mM}$ IPTG (lane 1) and chased in the presence of nonradioactive methionine for various times indicated at the top of the gel (lanes 2,3,4, and 5; chase for $7.5,15,30$, and $60 \mathrm{~min}$, respectively). Letters with an arrow indicate positions of $\mathrm{Pkn} 2$ (bands $a$ ) and other products from $\mathrm{pET} 11 / p k n 2$ (bands $b, c, d$ ). Bars with numbers at left indicate the positions of molecular mass markers $(\mathrm{kD})$.

(band a) as well as bands b, c, and d were detected (lane 2) as shown previously in Figure 5A. However, in all of the deletion mutations (lanes 3-14), band a disappeared completely and a new band appeared as indicated by a dot for each deletion mutation. The apparent molecular masses of these bands were estimated to be $105 \mathrm{kD}$ for $\triangle \mathrm{X}-\mathrm{B}$ (lane 4), 79 for $\Delta \mathrm{N}-\mathrm{B}$ (lane 6), 56 for $\Delta \mathrm{M}$-B (lane 8), 41 for $\Delta \mathrm{K}$-B (lane 10), 32 for $\Delta \mathrm{S}$-B (lane 12), and 50 for $\Delta \mathrm{Kn}$ (lane 14). The observed reduction of molecular masses for all of the construct is consistent with the deletion mutations depicted in Figure 7A, demonstrating that band $\mathrm{a}$ is the product of pkn2.

The total amounts of the $\beta$-lactamase products (bands $b+c+d$ ) are different depending on the constructs (Fig. $7 \mathrm{~B}$, see lanes 1-14). It is not known at present whether this is attributable to the readthrough from the T7 promoter or the effect of $P \mathrm{kn} 2$ products on the $\beta$-lactamase production.

\section{Band $b$ is the product of the bla gene}

In the deletion analyses of pkn2 shown in Figure 7B, one can observe that in contrast to band $a$, band $b$ did not disappear in $\Delta \mathrm{X}-\mathrm{B}$ and $\Delta \mathrm{N}-\mathrm{B}$ mutations (lanes 4 and 6, respectively). When the $3^{\prime}$-end region of $p k n 2$ was deleted beyond the $\mathrm{NcoI}$ site, the production of band b be- came almost undetectable (Fig. 7B, lanes 8, 10, and 12). In the case of $\Delta M-B$, a faint band appeared slightly below the band $b$ position, suggesting that this faint band may have something to do with band $b$. Note that the band at $41 \mathrm{kD}$ in $\Delta \mathrm{K}-\mathrm{B}$ (lane 10 ) is the truncated product of Pkn2 but not the band $\mathrm{b}$ product as discussed later. Interestingly, band c became a major product, and no band $\mathrm{b}$ was produced in $\Delta \mathrm{Kn}$ (lane 14).

It should be noted that band $\mathrm{b}$ was still produced in $\Delta N-B$ (lane 6 ) and that the plasmid for $\Delta N$-B contained the $1.5-\mathrm{kb}$ fragment from the $M$. xanthus chromosomal DNA that encompasses only the amino-terminal fragment of $\mathrm{Pkn} 2$ from residue 1 to 502. Therefore, band b was not likely to be derived from the $M$. xanthus DNA fragment. We thus speculated that the bla gene for ampicillin resistance encoding TEM- $\beta$-lactamase in the pET11a vector is responsible for the production of band $b$.

As shown in Figure 8A, the bla gene locates downstream of the pkn2 gene in the same orientation in a circular map of $\mathrm{pET} 11 / \mathrm{pkn} 2$. To determine that band $\mathrm{b}$ is really a product of the bla gene, the bla gene in pET11/ pkn2 was replaced with the $k^{2}{ }^{r}$ gene for kanamycin resistance from the $\mathrm{Tn} 5$ transposon as described in $\mathrm{Ma}$ terials and methods, and the resultant plasmid was designated $\mathrm{pET} 11 \mathrm{~km} / \mathrm{pkn} 2$. The cells harboring $\mathrm{pET} 11 /$ pkn2 and $\mathrm{pET} 11 \mathrm{~km} / \mathrm{pkn} 2$ were labeled with $\operatorname{Tran}^{35} \mathrm{~S}$ label for $30 \mathrm{~min}$ in the presence of rifampicin with or without the addition of IPTG. The labeled products were then analyzed by SDS-PAGE. As shown in Figure 8B, band a was still clearly detected in the presence of IPTG in cells harboring pET11 km/pkn2 (lane 4) as well as in cells harboring pET11/pkn2 (lane 2). However, band b, together with bands $c$ and d, completely disappeared in the cells harboring $\mathrm{pET} 11 \mathrm{~km} / p \mathrm{kn} 2$ in which the $\beta$-lactamase gene was replaced with the $k a n^{r}$ resistant gene (compare lane 4 with lane 2).

To confirm further that band $\mathrm{b}$ was derived from the bla gene, the same samples used in Figure 7B were analyzed by Western blot using anti- $\beta$-lactamase antibody. As shown in Figure $7 \mathrm{C}$, strong bands corresponding to band $\mathrm{b}$ were detected not only in the cells harboring pET11/pkn2 (lane 2) but also in the cells harboring $\mathrm{p} \Delta \mathrm{X}-\mathrm{B}$ (lane 4), and $\mathrm{p} \Delta \mathrm{N}-\mathrm{B}$ (lane 6). A faint band slightly below the band $\mathrm{b}$ position was also detected in cells harboring p $\Delta M-B$ (lane 8 ), which also coincides well with the faintly labeled band at the same position in Figure $7 \mathrm{~B}$, lane 8 .

In contrast to band $\mathrm{b}$, band $\mathrm{d}$ was detected in all lanes in Figure $7 \mathrm{C}$, indicating that it is $\beta$-lactamase, the product of the bla gene. The apparent molecular mass of band $\mathrm{d}(29 \mathrm{kD})$ also agrees well with the molecular mass of $\beta$-lactamase. It is not known at present why band d appears as a doublet form. The intensities of band $d$ were also very similar in all lanes regardless of the absence or the presence of IPTG, indicating that $\beta$-lactamase at band $d$ was synthesized from its own promoter. On the other hand, the production of bands $\mathrm{b}$ and $\mathrm{c}$ was observed only in the presence of IPTG and, thus, likely to be under the control of the T7 promoter of pET1la. On the basis of 
Figure 7. Analysis of the band $b$ product using various $p k n 2$ deletion mutants. $(A)$ Schematic diagram of $p k n 2$ and its deletion mutants. The method for constructing the deletion mutations is described in the text. (B) Expression of pkn2 and its deletion mutants. E. coli BL21 (DE3) harboring a plasmid containing individual pkn2 mutants was labeled with $\operatorname{Tran}^{35} \mathrm{~S}$-label for $2 \mathrm{hr}$ in the presence of rifampicin. $(-$ and +1 Without and with IPTG, respectively. (Lanes 1,2) Total cell extract from cells harboring pET11/pkn2; (lanes 3,4) from $\mathrm{p} \Delta \mathrm{X}$ $B$; (lanes 5,6$)$ from $\mathrm{p} \Delta \mathrm{N}-\mathrm{B}$; (lanes 7,8 ) from $\mathrm{p} \Delta \mathrm{M}-\mathrm{B}_{\text {; }}$ (lanes 9,10) from $\mathrm{p} \Delta \mathrm{K}-\mathrm{B}$; (lanes

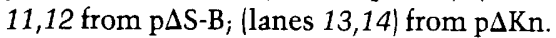
The products corresponding to individual deletion mutations are marked with dots. (C) Western blot analysis using anti- $\beta$-lactamase antiserum. The same sets of samples as used in $B$ were transferred on PVDF membrane to detect cross-reactive materials. Lanes 1 to 14 were the same as shown in $B$. Letters with an arrow and bars with a number are the same as in Fig. 6.

${ }^{A}$

A

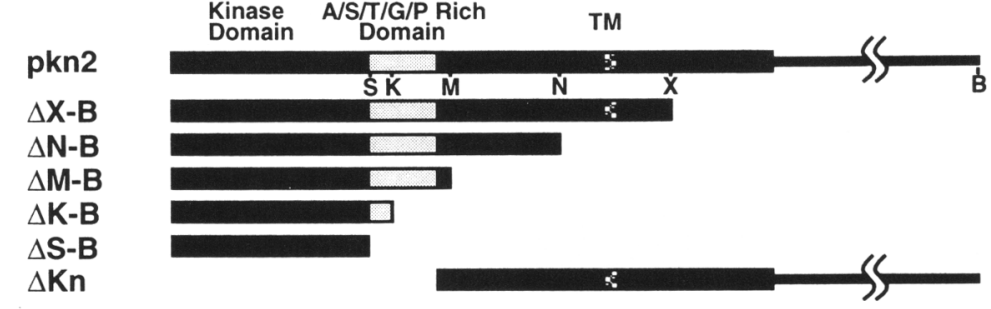

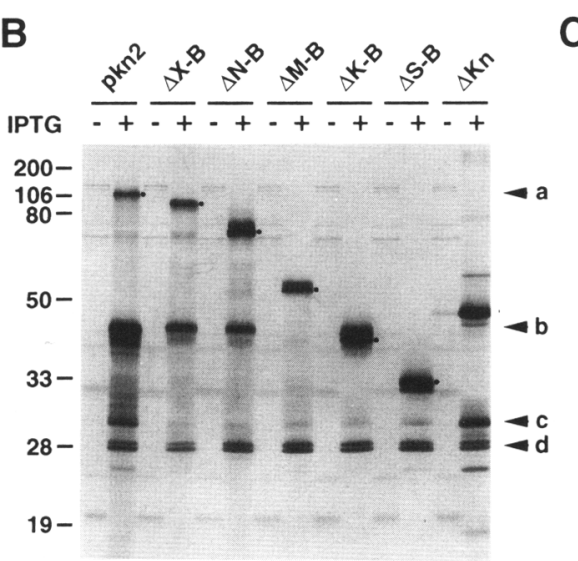

$\begin{array}{llllllllll}1 & 2 & 3 & 4 & 5 & 6 & 7 & 8 & 9 & 1011121314\end{array}$
C

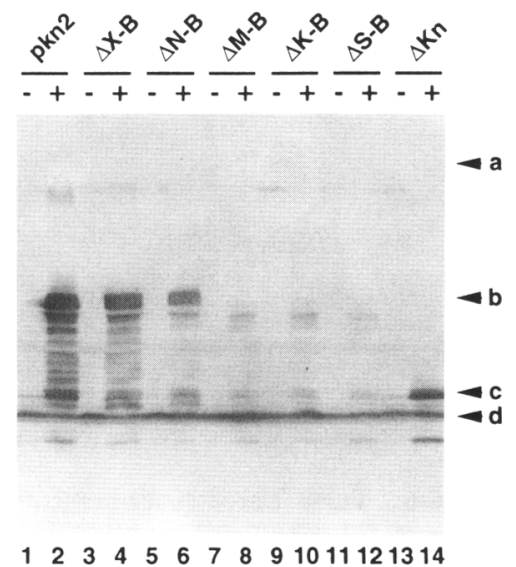

the apparent molecular mass of band $\mathrm{c}(31 \mathrm{kD})$, this band is considered to be the secretory precursor of $\beta$-lactamase, which still contains the uncleaved signal peptide of 23 amino acid residues.

The present results indicate that TEM- $\beta$-lactamase
A

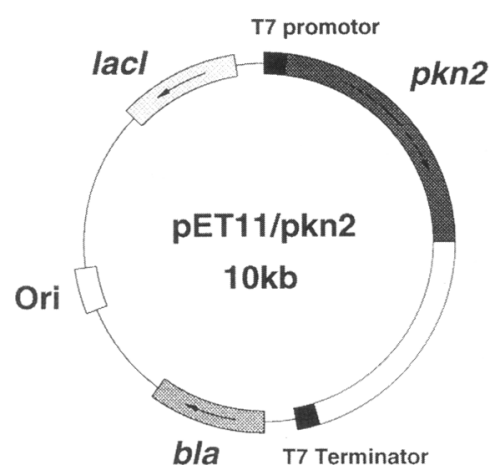

B

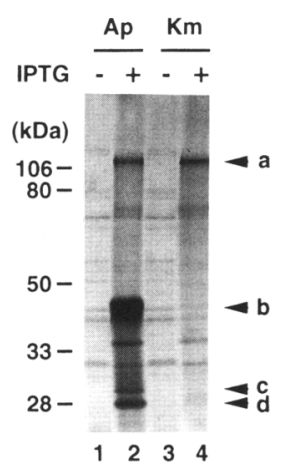

Figure 8. Circular map of $\mathrm{pET} 11 / \mathrm{pkn} 2(A)$ and SDS-PAGE patterns of cells harboring $\mathrm{pET} 11 / \mathrm{pkn} 2$ and $\mathrm{pET} 11 \mathrm{~km} / \mathrm{pkn} 2(B)$. (A) Locations of pkn2, bla, and lacI genes are represented by boxes, and their orientations are indicated by arrows in boxes. (B) E. coli BL21 (DE3) harboring pETIl/pkn2 and pETIl km/ pkn2 were labeled with $\operatorname{Tran}^{35}$ S-label for $2 \mathrm{hr}$ with (+ ) or without (-) IPTG. (Lanes 1,2) Cells harboring pET11/pkn2 without $(-)$ and with $(+)$ IPTG, respectively; (lanes 3,4$)$ cells harboring pET1 $1 \mathrm{~km} /$ pkn2 without $|-|$ and with $|+|$ IPTG, respectively. Assignments are the same as in Fig. 6. serves as a substrate for $\mathrm{Pkn} 2$, which can be phosphorylated very effectively at multiple threonine residues (Fig. $5 \mathrm{D} \mid$, resulting in the shift of the apparent molecular mass from 31 (band $\mathrm{c}$ ) to $44 \mathrm{kD}$ (band b). It is interesting to note that the Ala/Ser/Thr/Gly/Pro-rich domain of Pkn2 (see Fig. 7A) is required for kinase activity, because $\Delta \mathrm{K}-\mathrm{B}$ and $\Delta S$-B were unable to phosphorylate $\beta$-lactamase (Fig. $7 \mathrm{C}$, lanes 10 and 12 , respectively).

\section{Phosphorylation of $\beta$-lactamase and the Pkn2 regulatory domain}

Next, we examined whether Pkn2 phosphorylates $\beta$-lactamase produced by a separate plasmid. For this purpose, E. coli cells were transformed with both $\mathrm{pET} 11 \mathrm{~km} / \mathrm{pkn} 2$ and $\mathrm{p} \Delta \mathrm{Kn}$. The cells transformed with either plasmid or both were labeled with $\operatorname{Tran}^{35} \mathrm{~S}$-label in the presence of rifampicin. As shown in Figure 9A, Pkn2 became the major product in the cells harboring $\mathrm{pET} 11 \mathrm{~km} / \mathrm{pkn} 2$ when IPTG was added (band a in lane 2). In the cells harboring $\mathrm{p} \Delta \mathrm{Kn}$, three major bands appeared in the presence of IPTG (bands $c, d$, and $f$ in lane 4)-band $d$ for $\beta$-lactamase, band $c$ for pro- $\beta$-lactamase, and band $f$ for the truncated product of $\mathrm{Pkn} 2$. The same pattern was observed in Figure 7B, lane 14.

When cells harboring both plasmids were analyzed, two extra broad bands (bands $b$ and $e$ in lane 6) were detected in addition to bands $a, c, d$, and $f$. When the same sample used in Figure 9A was analyzed by Western blot using anti- $\beta$-lactamase antibody, not only bands $c$ and $d$, but also band $b$, were detected as shown in Figure 9B, lane 6, indicating that $\mathrm{Pkn} 2$ produced from a separate plasmid could phosphorylate $\beta$-lactamase precursor. 
A

B

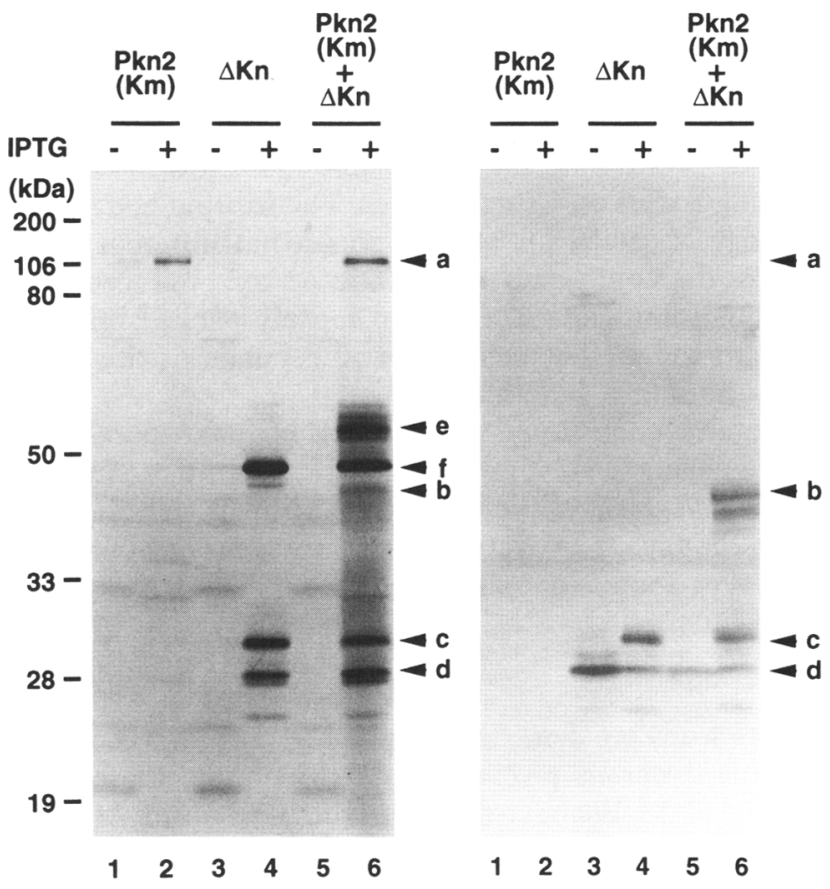

Figure 9. Phosphorylation of $\beta$-lactamase by $p k n 2$ expressed by a separate plasmid. $(A)$ Protein patterns of $E$. coli BL21 (DE3) harboring $\mathrm{pET} 1 \mathrm{~km} / \mathrm{pkn} 2$ (lanes 1,2), $\Delta \mathrm{Kn}$ (lanes 3,4), and $\mathrm{pET} 1 \mathrm{~km} / \mathrm{pkn} 2$ plus $\Delta \mathrm{Kn}$ (lanes 5,6 ). Cells were labeled with $\operatorname{Tran}^{35} \mathrm{~S}$-label for $2 \mathrm{hr}$ and analyzed by SDS-PAGE as described in Materials and methods. ( $e$ and $f$, with arrow) The positions of phosphorylated $\Delta \mathrm{Kn}$ and nonphosphorylated $\Delta \mathrm{Kn}$ polypeptide, respectively. $(B)$ Western blot analysis of $\beta$-lactamase phosphorylated by $P k n 2$. The same samples used in $A$ were analyzed by Western blot with anti- $\beta$-lactamase serum. (Lanes 1-6) The same as lanes $1-6$ in $A$. The assignments are the same as in Fig. 6.

Most importantly, Pkn2 was also able to phosphorylate the carboxy-terminal fragment of $\mathrm{Pkn} 2$ resulting in the formation of band e when both $\Delta \mathrm{Kn}$ and pkn2 were coexpressed.

\section{Association of Pkn2 with phosphorylated $\beta$-lactamase}

Because eukaryotic protein kinases are known to be associated with their substrates, we then examined whether Pkn2 forms a complex with $\beta$-lactamase. BL21(DE3) cells harboring pET11/pkn2 were labeled with $\operatorname{Tran}^{35} \mathrm{~S}$-label with or without rifampicin, as described in Materials and methods. Cell lysates were immunoprecipitated with anti-Pkn2 or anti- $\beta$-lactamase serum. As shown in Figure 10, lanes 4 and 10, phosphory. lated $\beta$-lactamase (band b) was coprecipitated with $\mathrm{Pkn} 2$ (band a) when anti-Pkn2 serum was used. Similarly, when the cell lysate was treated with anti- $\beta$-lactamase serum, Pkn2 (band a) was coprecipitated (lanes 6,12). Note that bands $c$ and $d$ in lanes 6 and 12 are pro- $\beta$ - lactamase and $\beta$-lactamase, respectively. It should be noted that bands $c$ and $d$ could not be detected with anti-Pkn2 serum \{lanes 4,10$\}$. These results demonstrate that phosphorylated $\beta$-lactamase forms a complex with Pkn2.

\section{Cellular localization of phosphorylated $\beta$-lactamase}

To examine the cellular localization of phosphorylated $\beta$-lactamase, cells harboring pET11/pkn2 were incubated with IPTG for $60 \mathrm{~min}$, and cellular fractionation was carried out by the method of Neu and Heppel (1965). As shown in Figure 11, phosphorylated $\beta$-lactamase, together with the precursor form of b-lactamase (band c), was detected in both the membrane and the cytoplasmic fractions (lanes 4 and 5, respectively), but not in the periplasmic fraction (lane 3). In contrast, the mature form of $\beta$-lactamase was found primarily in the periplasmic fraction (lane 3). The periplasmic localization of mature $\beta$-lactamase is particularly evident in the control experiment with p2 $2 \mathrm{Kn}$ (lane 8). Note that no band $\mathrm{b}$ was produced in the control experiment (lanes 6-10). These results indicate that the phosphorylation of $\beta$-lactamase blocks its secretion across the membrane resulting in the accumulation of phosphorylated $\beta$-lactamase in the cytoplasm as well as in the membrane fraction.

\section{Expression of $\mathrm{pkn} 2$ in $\mathrm{M}$. xanthus}

$M$. xanthus strain $p k n 2 / Z$ was constructed, which contained intact $p k n 2$ as well as $p k n 2-l a c Z$ fusion. The $p k n 2 / Z$ strain was plated on CYE agar plate for vegetative growth as well as on CF agar plate for fruiting body formation. X-gal (5-bromo-4-chloro-3-indolyl- $\beta$-D-galac-

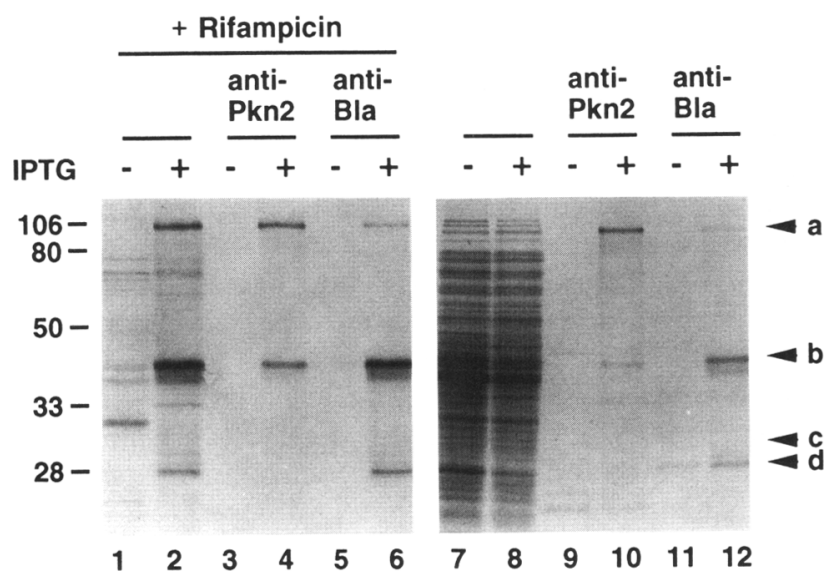

Figure 10. Coimmunoprecipitation of $\mathrm{Pkn} 2$ and $\beta$-lactamase. E. coli BL21 (DE3) harboring pET11/pkn2 was labeled with $\mathrm{Tran}^{35} \mathrm{~S}$-label for $2 \mathrm{hr}$ in the presence (lanes $\left.1-6\right)$ or the absence (lanes 7-12) of rifampicin. Immunoprecipitation was performed with anti-Pkn2 (lanes $3,4,9,10$ ) or anti- $\beta$-lactamase (lanes $5,6,11,12$ ), as described in Materials and methods. (Lanes $1,2,7,8)$ Total cell extracts without $(-)$ and with ( + | IPTG. Letters with an arrow and bars with a number are the same as in Fig. 6. 

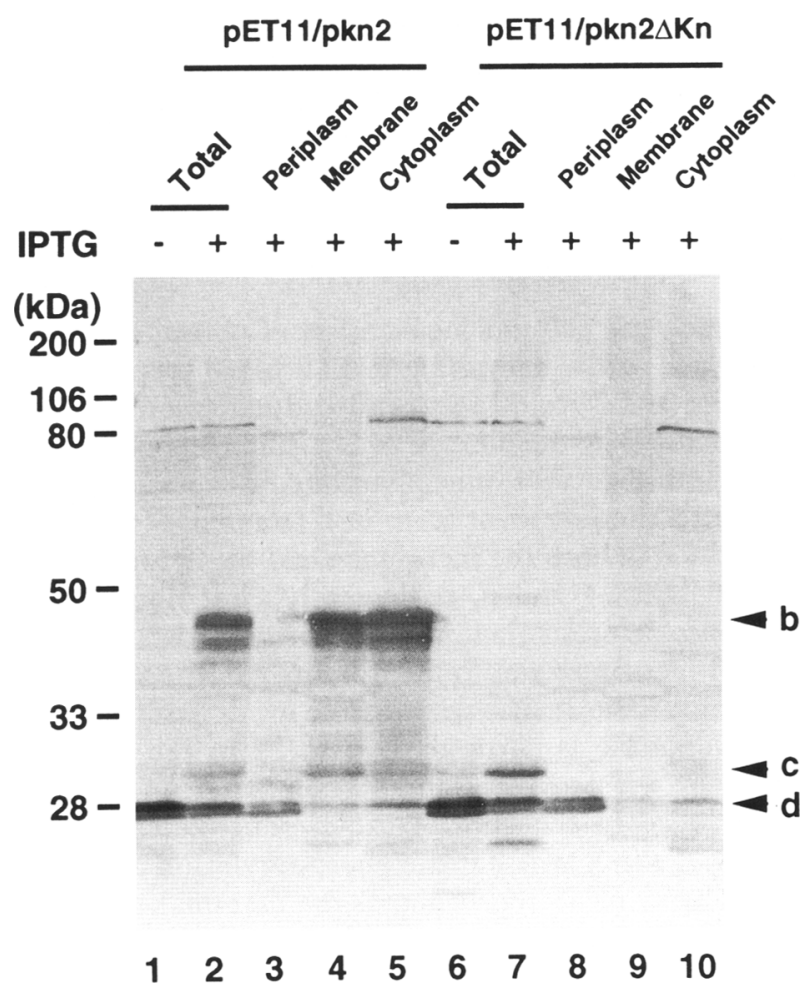

Figure 11. Cellular localization of phosphorylated $\beta$-lactamase. E. coli BL21 (DE3) harboring pET11/pkn2 or pET11/ $p k n 2 \Delta \mathrm{Kn}$ were labeled with $\operatorname{Tran}^{35} \mathrm{~S}$-label for $2 \mathrm{hr}$ and fractionated into the periplasmic membrane and cytoplasmic fractions, as described in Materials and methods. After SDS-PAGE, the proteins were transferred to PVDF membrane and detected using anti- $\beta$-lactamase serum. (Lanes $1,2,6,7)$ Total cell lysate; (lanes 3,8 ) periplasmic fraction; (lanes 4,9 ) membrane fraction; (lanes 5,10 ) cytoplasmic fractions. Equal portions of the periplasmic, membrane, and cytoplasmic fractions were applied to the gel. The assignments are the same as in Fig. 6.

topyranoside/ was added to the agar plates to detect $\beta$ galactosidase expression. Blue colonies became visible after $\sim 48 \mathrm{hr}$ incubation at $30^{\circ} \mathrm{C}$ on the CYE plates, whereas no blue color was developed on the CF plates. These results indicate that $p k n 2$ is expressed only during the vegetative growth but not during development.

A more quantitative analysis of the expression of $p k n 2$ was obtained by assaying $\beta$-galactosidase activity in the $p k n 2 / Z$ strain during both vegetative growth and the developmental cycle. The specific $\beta$-galactosidase activities were between 3 and $5 \mathrm{U} / \mathrm{mg}$ of protein $/ \mathrm{min}$ during the exponential growth and sharply dropped to $<1$ during the stationary phase. $\beta$-Galactosidase activity on CF agar plates decreases rapidly and stayed at a very low level of $<2 \mathrm{U} / \mathrm{mg}$ of protein $/ \mathrm{min}$. These results are consistent with the plating experiment described above, indicating that $p k n 2$ is mainly expressed during the late exponential growth phase.

Effects of a disruption mutation of $\mathrm{pkn} 2$

As described in Materials and methods, the pkn2 gene on the chromosome was disrupted by inserting the $k a n^{\mathrm{r}}$ gene from Tn5 into the unique SalI site that lies within the coding region for subdomain IV of the $\mathrm{Pkn} 2$ catalytic domain forming strain $\Delta p k n 2$. Strain $\Delta p k n 2$ was found to grow normally as the wild-type strain in CYE medium, indicating that $p k n 2$ is not essential for vegetative growth. Strain $\Delta p k n 2$ was also able to form well-defined fruiting bodies on CF agar plates. The fruiting body morphology of strain $\Delta p k n 2$ was somewhat different from that of the wild-type strain; strain $\Delta p k n 2$ produced continuous mounds that appeared loosely packed, in contrast to the well-separated round mounds of the wildtype strain (not shown).

We also quantitated the number of myxospores produced during development. The $\Delta p k n 2$ spore production was $-30 \%-50 \%$ of the level of the wild-type strain. The $\Delta p k n 2$ myxospores were viable at the same level as the wild-type spores (not shown).

\section{Discussion}

In this study we demonstrated that $M$. xanthus contains a transmembrane protein serine/threonine kinase, designated $\mathrm{Pkn} 2$. We have described previously that $M$. xanthus contains a cytoplasmic protein serine/threonine kinase, Pkn1 (Munoz-Dorado et al. 1991). Pkn2, consisting of 830 amino acid residues, contains the 11 subdomains characteristic of the eukaryotic protein kinases at the amino-terminal region. Immediately after the last conserved subdomain XI, there is a 99-residue region (from residue 275 to 373 ) enriched with serine (20 residues), threonine (10), alanine (23), glycine (17), and proline (10). These residues account for $81 \%$ of this region. This domain may be the site for phosphorylation, having a total 35 serine plus threonine residues in this region, and the phosphorylation of this domain may be involved in the regulation of $\mathrm{Pkn} 2$ function.

From the PhoA fusion analysis, the 207-residue carboxy-terminal domain immediately after the 18-residue hydrophobic domain was found to be translocated across the membrane, which is likely to serve as a receptor to sense an external signal yet to be identified. Most significantly, it was found that $\mathrm{Pkn} 2$ is a protein kinase that is able to phosphorylate threonine residues of TEM- $\beta$-lactamase specifically. Our data indicate that only nascent $\beta$-lactamase was phosphorylated, which prevented the translocation of $\beta$-lactamase across the membrane. TEM- $\beta$-lactamase contains a total of 20 threonine residues, of which 5 residues are found in known phosphorylation site motifs (R/KXXT and R/KXT; Hunter 1991). Consistent with this fact, five radioactive tryptic peptides were obtained when phosphorylated $\beta$-lactamase was digested with trypsin. These results indicate that Pkn2 phosphorylates $\beta$-lactamase at multiple sites to block its secretion. At present, it is not known whether phosphorylated $\beta$-lactamase still contains the signal peptide.

$M$. xanthus is known to be highly resistant to ampicillin, and a $\beta$-lactamase, which is cross-reactive with anti-TEM- $\beta$-lactamase senum has been identified in this 
organism (K. $\mathrm{O}^{\prime}$ Connor and D. Zusman, pers. comm.). It is tempting to speculate that $\mathrm{Pkn} 2$ may regulate the activity of $\beta$-lactamase and/or other enzymes related to $\beta$-lacatamase such as penicillin-binding proteins by phosphorylating them under certain conditions. In this fashion, cell viability, cell shapes, or morphology may be regulated under certain circumstances.

In eukaryotes, most protein serine/threonine kinases are soluble localizing in the cytoplasm. However, a few protein serine/threonine kinases, such as transforming growth factor (TGF)- $\beta$ receptor (Massaqué et al. 1994) and IRE1 (Cox et al. 1993), are known to be transmembrane protein kinases. $\mathrm{Pkn} 2$ is the first transmembrane protein serine/threonine kinase ever found in prokary. otes. In prokaryotes, a large number of transmembrane protein histidine kinases are known, which function as sensors for various external signals (Stock et al. 1989). It remains to be elucidated how $M$. xanthus differentially utilizes two types of transmembrane kinases in terms of their functions. It is also an intriguing question how $M$. xanthus acquired the serine/threonine kinase gene during the course of evolution.

\section{Materials and methods}

\section{Materials}

$\left[\alpha^{-32} \mathrm{P}\right] \mathrm{dCTP},\left[\gamma^{-32} \mathrm{P}\right] \mathrm{ATP},\left[\alpha^{-35} \mathrm{~S}\right] \mathrm{dATP}$, and ${ }^{32} \mathrm{P}$ were purchased from Amersham, and $\operatorname{Tran}^{35} \mathrm{~S}$-label containing $l^{35} \mathrm{~S} \mid$ methionine and $\left.{ }^{35} \mathrm{~S}\right]$ cysteine from ICN. DNA sequencing was performed with a Sequenase kit obtained from U.S. Biochemical. Taq polymerase for PCR was purchased from Perkin-Elmer Cetus, restriction enzymes from New England Biolabs, and T4 DNA ligase from Bethesda Research Laboratories.

\section{Bacterial strains and growth conditions}

M. xanthus DZF1 was grown at $30^{\circ} \mathrm{C}$ in CYE medium /Campos and Geisselsoder 1978), and $40 \mu \mathrm{g} / \mathrm{ml}$ of kanamycin was added when necessary.

$M$. xanthus fruiting bodies were obtained on CF agar plates (Hagen et al. 1978), and the samples were harvested and treated as reported previously (Munoz-Dorado et al. 1991).

E. coli JM83 (Vieira and Messing 1982) and E. coli CL83 (Lerner and Inouye 1990) were used as recipient strains for transformation and P1 infection. Cells were grown in LB medium (Miller 1972) supplemented with $50 \mu \mathrm{g} / \mathrm{ml}$ of ampicillin, 25 $\mu \mathrm{g} / \mathrm{ml}$ of kanamycin, and/or $10 \mu \mathrm{g} / \mathrm{ml}$ of chloramphenicol when necessary. E. coli BL21(DE3) was used for the T7 RNA polymerase expression system (Studier et al. 1990). This strain was grown in $\mathrm{M} 9$ medium containing 19 amino acids, excluding methionine, when cells were labeled with $\operatorname{Tran}^{35} \mathrm{~S}$-label or in a low phosphate medium when the cells were labeled with ${ }^{32} \mathrm{P}$ (Munoz-Dorado et al. 1991). E. coli strains were grown at $37^{\circ} \mathrm{C}$. E. coli CCl 18 was used for the alkaline phosphatase assay (Manoil and Beckwith 1985).

\section{Plasmids and phages}

pUC9 (Vieira and Messing 1982) and pUX (Dhundale et al. 1988) were used for cloning, subcloning, and sequencing. pETlla was used for the expression of $M$. xanthus genes in E. coli by the T7 RNA polymerase system (Studier et al. 1990). pPlEK was derived from pUC19 and contained a 5.4-kb EcoRI-KpnI fragment encoding P1-specific incompatibility (Hsu et al. 1989). pKM005 was derived from pINIII-A3 and contained the $1 a c Z$ gene without a promoter from $E$. coli (Masui et al. 1983). pUC7Kan5 and pUC9Kn(Pst $\left.{ }^{-}\right)$were derivatives of pUC7 and pUC9, respectively, constructed by S. Inouye (unpubl.); they contained the $k a n^{r}$ amycin resistance gene from Tn5. Phage Plclr $100 \mathrm{Cm}$ (Rosner 1972) was used to transduce cloned DNA from E. coli to M. xanthus.

\section{DNA manipulation and sequencing}

$M$. xanthus chromosomal DNA was prepared according to the method of Avery and Kaiser (1983) and phage $\lambda$ DNA according to the method of Maniatis et al. (1982). Southern blot analysis was performed by the method described by Southern (Southern 1975). Phage plaques were blotted to nitrocellulose filters by contact, and $M$. xanthus and $E$. coli colonies were grown on Whatman $3 \mathrm{MM}$ papers; the filters were treated as described previously (Inouye and Inouye 1987). The DNA probes were labeled by nick translation, and hybridization was carried out at $42^{\circ} \mathrm{C}$ in $50 \%$ formamide as reported (Maniatis et al. 1982). DNA sequencing was determined by the dideoxynucleotide chain termination method (Sanger et al. 1977) using double-stranded plasmid DNA and the universal primers and the synthetic oligonucleotides designed from newly obtained DNA sequences as primers.

\section{Construction of pkn2 and its deletion mutants under a $T 7$ promoter}

To clone the pkn2 gene under the control of the $T 7$ promoter in pETlla, an Ndel site was first created at the initiation codon of the pkn2 gene by PCR, using the following two primers; $5^{\prime}$ AAGATAAGCTTCATATGCTGGCCCCTGACTCCCTT-3'; which annealed at position 393-412 (Fig. 3) and contained NdeI and HindIII sites, and 5'-GCAGGCGTGGTCGCCGGATT-3'; which annealed at position 633-652, immediately downstream of the SalI site (619-624). The fragment amplified was digested with HindIII and Sall and ligated to PIMPK2S with HindIII digestion and partial digestion with Sall. The plasmid thus obtained (pJMPK2HB) was then digested with NdeI and BamHI, and the resulting 5-kb fragment was ligated to pETl la digested with the same enzymes. The plasmid thus obtained was designated pET11/pkn2. In the case of $\Delta \mathrm{Kn}$, the primers used were 5'-AACAAGCTTCATATGCTCACCGACATCCAG-3' (position 1583-1600), which contained HindIII and NdeI sites, and 5'-ACATGCTCCACGGCCTCG-3' (position 1912-1929), which annealed downstream of the NcoI site at position 18991904 (see Fig. 3). The fragment amplified was digested with HindIII and NcoI and ligated to PIMPK2HB digested with HindIII and partially with $\mathrm{Ncol}$. The plasmid obtained was then digested with NdeI and $B a m H I$, and the resulting 4-kb fragment was ligated to pETll a linearlized with the same enzymes. This plasmid was designated $\mathrm{p} \Delta \mathrm{Kn}$.

The carboxy-terminal deletion mutations of $\mathrm{Pkn} 2(\mathrm{p} \Delta \mathrm{X}-\mathrm{B}$, $\mathrm{p} \Delta \mathrm{N}-\mathrm{B}, \mathrm{p} \Delta \mathrm{M}-\mathrm{B}, \mathrm{p} \Delta \mathrm{K}-\mathrm{B}$, and $\mathrm{p} \Delta \mathrm{S}-\mathrm{B}$ ) were constructed by digesting pET1l/pkn2 at the BamHI site and another unique restriction enzyme site described in the text and Figure 8 , followed by ligation after filling in at the cleaved sites with the Klenow fragment of DNA polymerase I.

\section{Expression of $\mathrm{pkn} 2$ and its deletion mutants in $\mathrm{E}$. coli}

Using E. coli BL21 (DE3) harboring pET11/pkn2 or its deletion constructs, the expression of pkn2 or its mutated genes was induced by addition of $1 \mathrm{mM}$ IPTG for $1 \mathrm{hr}$. Rifampicin (150 $\mu \mathrm{g} / \mathrm{ml}$ ) was then added, and the culture was incubated further for $15 \mathrm{~min}$. After treatment the cells were labeled with $\operatorname{Tran}^{35} \mathrm{~S}$ - 
label for a period specified in each experiment. Pulse-chase experiments were performed by labeling for $5 \mathrm{~min}$ without adding rifampicin and chasing in the presence of $200 \mu \mathrm{g} / \mathrm{ml}$ of nonradioactive methionine at various times.

\section{Western blot analysis}

After SDS-PAGE, the samples were transferred onto a PVDF membrane using a Sartblot semidry transfer apparatus as recommended by the manufacturer (Sartorious, Gottingen, Germany). $\beta$-Lactamase was detected by anti- $\beta$-lactamase serum subjecting anti-rabbit IgG conjugated to alkaline phosphate (Bio-Rad) with chromogenic substrates.

\section{Immunoprecipitation of Pkn2 and its mutants,} and $\beta$-lactamase

Ten-milliliter cultures of E. coli BL21(DE3) harboring various plasmids were labeled with $\operatorname{Tran}^{35} \mathrm{~S}$-label as described previously. The cells were harvested, washed with $50 \mathrm{~mm}$ Tris- $\mathrm{HCl}$ (pH 8.0), and then suspended in $50 \mu$ l sonication buffer $[50 \mathrm{mM}$ Tris- $\mathrm{HCl}$ ( $\mathrm{pH} 8.0$ ), $1 \mathrm{mM}$ PMSF, $1 \mathrm{mM}$ EDTA, and $2 \mathrm{~mm} \beta$-mercaptoethanol]. After sonication, cell debris was removed by low centrifugation and $500 \mu \mathrm{l}$ of TENN $[50 \mathrm{~mm}$ Tris- $\mathrm{HCl}(\mathrm{pH} 8.0)$, $140 \mathrm{~mm} \mathrm{NaCl}, 5 \mathrm{~mm}$ EDTA, $0.5 \% \mathrm{NP}-40$ ] was added. After the addition of $5 \mu \mathrm{l}$ of anti- $\beta$-lactamase serum, the mixture was incubated on ice for $1 \mathrm{hr}$, and then $5 \mu \mathrm{l}$ of Staphylococcus aureus ghosts purchased from Sigma was added. After 15 min at room temperature, precipitates were recovered by centrifugation $(10,000 \mathrm{~g}$ for $1 \mathrm{~min})$, washed three times with TENN, suspended in SDS-PAGE sample buffer [ $80 \mathrm{~mm}$ Tris- $\mathrm{HCl}(\mathrm{pH} 6.8)$, $2 \%$ SDS, $0.2 \mathrm{M} \beta$-mercaptoethanol, $10 \%$ glyceroll, and analyzed on $15 \%$ SDS-PAGE after boiling. The gel was dried and autoradiographed.

\section{Cellular fractionation}

Isolation of periplasmic, membrane, and cytoplasmic fractions was carried out according to the method by Neu and Heppel (1965). Briefly, E. coli cells grown at Klett 100 in $10 \mathrm{ml}$ of M9 medium with or without induction of IPTG were harvested by centrifugation at $5000 \mathrm{~g}$ for $10 \mathrm{~min}$ at $4^{\circ} \mathrm{C}$, and the cell pellet was washed with $10 \mathrm{~mm}$ Tris- $\mathrm{HCl}(\mathrm{pH} 8.0)$. The washed cells were resuspended into $1 \mathrm{ml}$ of $20 \%$ sucrose in $30 \mathrm{mM}$ Tris- $\mathrm{HCl} / \mathrm{pH}$ 8.0) containing $1 \mathrm{mM}$ EDTA, and the suspension was incubated for $10 \mathrm{~min}$ at room temperature. The cell suspension was then spun at $13,000 \mathrm{~g}$ for $10 \mathrm{~min}$ at $4^{\circ} \mathrm{C}$, and after the addition of $1 \mathrm{ml}$ of ice-cold water to the cell pellet, the cell suspension was incubated for $10 \mathrm{~min}$ at $4^{\circ} \mathrm{C}$. The cell suspension was centrifuged at $5000 \mathrm{~g}$ for $10 \mathrm{~min}$ at $4^{\circ} \mathrm{C}$, and the supernatant was used as the periplasmic fraction. The cell pellet was then disrupted by sonication in $0.5 \mathrm{ml}$ of $50 \mathrm{~mm}$ Tris- $\mathrm{HCl}$ (pH 8.0), $1 \mathrm{~mm}$ EDTA, $1 \mathrm{mM}$ phenylmethane sulfonyl fluoride (PMSF), and $2 \mathrm{mM} \beta$-mercaptoethanol. The cell debris and unbroken cells were removed by centrifugation at $5000 \mathrm{~g}$ for $10 \mathrm{~min}$ at $4^{\circ} \mathrm{C}$ and the supernatant was fractionated into the membrane and cytoplasmic fractions by ultracentrifugation at $100,000 \mathrm{~g}$ for $30 \mathrm{~min}$ at $4^{\circ} \mathrm{C}$.

\section{Construction of pkn2-phoA fusion genes and PhoA assay}

The DNA fragments, with or without the region encompassing a putative transmembrane domain, were amplified by PCR using pIMPK2HB as a template and the following oligonucleotides as primers. P1 (5'-CTAAGCTTGGGCAACGCGCTCGCG3-') corresponds to the region from amino acid 576 to 580 in Figure 3 . This primer contains a HindIII site at the $5^{\prime}$ end that enables in-frame fusion of the $p k n 2$ fragments with the $\alpha$-fragment of $l a c Z$ in pUC9. P2 15'-CTCTGCAGCCTCGCGCCTCCGCTG- $\left.3^{\prime}\right)$ and P3 (5'-CTCTGCAGCGGCGGCGTCCATCAG-3') correspond to the region from residue 601 to 605 and from residue 648 to 652 in Figure 3, respectively. They have a PstI site at the 3 ' end to enable the in-frame fusion of the pkn2 fragments with the phoA gene in pCH2 (Hoffman and Wright 1985). PCR-amplified fragments were digested with HindIII and PstI and cloned in the HindIII and PstI sites of pUC9. The resulting plasmids were digested with $P$ st I, and the $3-\mathrm{kb}$ Pst I fragment containing the phoA gene from $\mathrm{pCH} 2$ was ligated into the PstI site, followed by determination of the correct orientation of the phoA gene. Using the resulting plasmids, ppkn2-phoA-1 and -2 , the expression of the $p h o A$ gene was under the control of the lac promoter-operator. Before PhoA assay, cells were incubated in M9 medium in the presence of $1 \mathrm{mM}$ IPTG for $2 \mathrm{hr}$. PhoA activity was measured as described previously (Brickman and Beckwith 1975).

\section{Phosphoamino acid analysis}

E. coli BL21 (DE3) haboring pET11/pkn2 was labeled in vivo with ortho- ${ }^{32} \mathrm{P}$ as described previously (Munoz-Dorado et al. 1991). Phosphoamino acid analysis was carried out as described previously (Kamps and Sefton 1989).

\section{Construction of the $\mathrm{pkn} 2 / \mathrm{Z}$ strain}

To fuse the $p k n 2$ gene to $l a c Z$, a $B a m H I$ site was created in the pkn2 gene in-frame with the BamHI site of lacZ in pKM005 by PCR. The reaction was performed with the oligonucleotides 5'-GGCCGCGGGATCCAGGGGCAGCGG-3', which anneals at position 1090-1113 (Fig. 3) and contains a BamHI site; and the oligonucleotide 5'-AATTTCACACAGGAAACAGCTATG-3', which anneals to pUC9 near the EcoRI site of the polylinker region. After 25 cycles, the 1.1-kb PCR product obtained was purified, digested with EcoRI and BamHI, and ligated to pUC9 digested with the same enzymes. This plasmid was designated PJMPK2EB, and its sequence was confirmed by partial sequencing. The 1.1-kb fragment obtained after digestion of pIMPK2EB with EcoRI and BamHI, the 6.2-kb BamHI-SalI fragment of pKM005, and the $1.45-\mathrm{kb}$ Sall-EcoRI fragment of pUC9Km(Pst $\left.{ }^{-}\right)$were then ligated to plasmid pPlEK digested with SalI. The resulting plasmid was then transferred from $E$. coli to $M$. xanthus by $\mathrm{P} 1$ transduction as reported previously (Shimkets et al. 1983). M. xanthus colonies containing the fused gene were selected with kanamycin, and one of them was characterized further for the expression of $p k n 2$. This strain was designated $p k n 2 / Z$.

\section{Construction of a $\Delta \mathrm{pkn} 2$ strain in M. xanthus}

The pkn2 gene was disrupted by insertion of $k a n^{r}$ of Tn5 lobtained by the Sall digestion of pUC7Kan5) into the unique SalI site of pIMPK2X (see Fig. 2). The plasmid thus obtained was designated pJMPK2XKan. From this plasmid the disrupted gene was obtained by digestion with $\mathrm{XhoI}$, and the 3.8 -kb fragment was ligated to pPIEK digested with Sall. This plasmid was then transferred from $E$. coli to $M$. xanthus by $\mathrm{P} 1$ transduction (Shimkets et al. 1983). The kanamycin-resistant colonies were screened for double crossover events using $\mathrm{pUC} 9$ as a probe. The replacement of the wild-type gene by the disrupted gene was confirmed by Southern blot analysis using the 4.8 -kb Sall fragment containing $p k n 2$ as a probe. This strain was designated $\Delta p k n 2$.

\section{Acknowledgments}

We acknowledge Dr. W.A. Hanlon for his critical reading of this manuscript. This work was supported by a grant from the $\mathrm{Na}$ - 
tional Institutes of Health-National Institute of General Medical Sciences (GM44012).

The publication costs of this article were defrayed in part by payment of page charges. This article must therefore be hereby marked "advertisement" in accordance with 18 USC section 1734 solely to indicate this fact.

\section{References}

Apelian, D. and S. Inouye. 1990. Development-specific sigma factor essential for late stage differentiation of Myxococcus xanthus. Genes \& Dev. 4: 1396-1403.

Avery, L. and D. Kaiser. 1983. In situ transposon replacement and isolation of spontaneous tandem duplication. Mol. \& Gen. Genet. 191: 99-109.

Brickman, E. and J. Beckwith. 1975. Analysis of the regulation of Escherichia coli alkaline phosphatase synthesis using deletions and $\phi 80$ transducing phages. I. Mol. Biol. 96: 307316.

Campos, J.M. and J. Geisselsoder, J. 1978. Isolation of bacteriophage $\mathrm{Mx}-4$, a generalized transducing phage for Myxococcus xanthus. I. Mol. Biol. 119: 167-178.

Cox, J.S., C.E. Shamu, and P. Walter. 1993. Transcription induction of genes encoding endoplasmic reticulum resident proteins requires a transmembrane protein kinase. Cell 73: 1197-1206.

Dhundale, A., T. Furuichi, M. Inouye, and S. Inouye. 1988. Mutations that affect production of bacterial RNA-linked msDNA in Myxococcus xanthus. /. Bacteriol. 170: 5620-5624.

Gafvelin, G. and G. von Heijne. 1994. Topological "frustration" in multispanning E. coli inner membrane proteins. Cell 77: 401-412.

Gennity, J.M. and M. Inouye. 1991. Protein secretion in bacteria. Curr. Opin. Biotechnol. 2: 661-667.

Hagen, D.C., A.P. Bretscher, and D. Kaiser. 1978. Synergism between morphogenetic mutants of Myxococcus xanthus. Dev. Biol. 64: 383-390.

Hanks, S.K., M. Quinn, and T. Hunter. 1988. The protein kinase family: Conserved features and deduced phylogeny of the catalytic domains. Science 241: 42-52.

Hoffman, C.S., and A. Wright. 1985. Fusions of secreted proteins to alkaline phosphatase: An approach for studying protein secretion. Proc. Natl. Acad. Sci. 82: 5107-5111.

Hsu, M-Y., S. Inouye, and M. Inouye. 1989. Structure requirements of the RNA precursor for the biosynthesis of the branched RNA-linked multicopy single-stranded DNA of Myxococcus xanthus. J. Biol. Chem. 264: 6214-6219.

Hunter, T. 199l. Protein kinase classification. Methods Enzymol. 200: 62-76.

Inouye, S. and M. Inouye. 1987. Oligonucleotide-directed sitespecific mutagenesis using double-stranded plasmid DNA. In Synthesis and application of DNA and RNA led. S.A. Narang), pp. 181-204. Academic Press, Orlando, FL.

Inouye, S., M-Y. Hsu, S. Eagle, and M. Inouye. 1989. Reverse transcriptase associated with the biosynthesis of the branched RNA-linked msDNA in Myxococcus xanthus. Cell 56: 709-717

Kamps, M.P. and B.M. Sefton. 1989. Acid and base hydrolysis of phosphoproteins bound to immobilon facilitates analysis of phospho amino acids in gel-fractionated proteins. Anal. Biochem. 176: 22-27.

Kim, H., S. Paul, J.M. Gennity, and M. Inouye. 1994. Reversible topology of a bifunctional transmembrane protein depends upon the charge balance around its transmembrane domain. Mol. Microbiol. 11: 819-831.

Klingenberg, M. 1990. Mechanism and evolution of the uncou- pling protein of brown adipose tissue. Trends Biochem. Sci. 15: 108-112.

Lerner, C.G. and M. Inouye. 1990. Low copy number plasmids for regulated low-level expression of cloned genes in Escherichia coli with blue/white insert screening capability. Nucleic Acids Res. 18: 4631.

Lin, C.R., M.S. Kapiloff, S. Durgerian, K. Tatemoto, A.F. Russo, P. Hanson, H. Schulman, and M.G. Rosenfeld. 1987. Molecular cloning of a brain-specific calcium/calmodulin-dependent protein kinase. Proc. Natl. Acad. Sci. 84: 5962-5966.

Lorenz, W., J. Inglese, K. Palczewski, J.J. Onorato, M.G. Caron, and R.J. Lefkowitz. 1991. The receptor kinase family: Primary structure of Rhodopsin kinase reveals similarities to the $\beta$-adrenergic receptor kinase. Proc. Natl. Acad. Sci. 88: 8715-8719.

Maniatis, T., E.F. Fritsch, and J. Sambrook. 1982. Molecular cloning: A laboratory manual. Cold Spring Harbor Laboratory, New York.

Manoil, C. and J. Beckwith. 1985. Tn phoA: A transposon probe for protein export signals. Proc. Natl. Acad. Sci. 82: 8129-8133.

Massagué, J., L. Attisano, and J.L. Wrana. 1994. The TGF- $\beta$ family and its composite receptors. Trends Cell Biol. 4: 172-178.

Masui, Y., J. Coleman, and M. Inouye. 1983. Multipurpose expression cloning vehicles in Escherichia coli. In Experimental manipulation of gene expression (ed. M. Inouye), pp. 1532. Academic Press, New York.

Miller, J.H. 1972. Experiments in molecular genetics. Cold Spring Harbor Laboratory, New York.

Munoz-Dorado, J., S. Inouye, and M. Inouye. 1991. A gene encoding a protein serine/threonine kinase is required for normal development of $M$. xanthus, a Gram-negative bacterium. Cell 67: 995-1006.

Nelson, D.R., J.E. Lawson, M. Klingenberg, and M.G. Douglas. 1993. Site-directed mutagenesis of the yeast mitochondrial ADP/ATP translocator. J. Mol. Biol. 230: 1159-1170.

Neu, H.C. and L.A. Heppel. 1965. The release of enzymes from Escherichia coli by osmotic shock and during the formation of spheroplasts. I. Biol. Chem. 240: 3685-3692.

Pugsley, A.P. 1993. The complete general secretory pathway in Gram-negative bacteria. Microbiol. Rev. 57: 50-108.

Rosner, J.L. 1972. Formation, induction and curing of bacteriophage P1 lysogens. Virology 49: 679-689.

Sanger, F., S. Nicklen, and A.S. Coulson. 1977. DNA sequencing with chain terminating inhibitors. Proc. Natl. Acad. Sci. 74: 5463-5467.

Shimkets, L.J. 1990. Social and developmental biology of the myxobacteria. Microbiol. Rev. 54: 473-501.

Shimkets, L.J., R.E. Gill, and D. Kaiser. 1983. Developmental cell interaction in Myxococcus xanthus and the spoC locus. Proc. Natl. Acad. Sci. 80: 1406-1410.

Southern, E.M. 1975. Detection of specific sequences among DNA fragments seperated by gel electrophoresis. I. Mol. Biol. 98: 503-517.

Stock, J.B., A.J. Ninfa, and A.M. Stock. 1989. Protein phosphorylation and regulation of adaptive response in bacteria. $\mathrm{Mi}$ crobiol. Rev. 53: 450-490.

Studier, F.W., A.H. Rosenberg, J.J. Dunn, and J.W. Dubendorff. 1990. Use of T7 RNA polymerase to direct expression of cloned genes. Methods Enzymol. 185: 60-89.

Vieira, J. and J. Messing. 1982. The pUC plasmids, an M13mp7derived system for insertion, mutagenesis and sequencing with synthetic universal primers. Gene 19: 259-268.

Zhang, W., J. Munoz-Dorado, M. Inouye, and S. Inouye. 1992. Identification of a putative eukaryotic-like protein kinase family in the developmental bacterium Myxococcus xanthus. J. Bacteriol. 174: 5450-5453. 


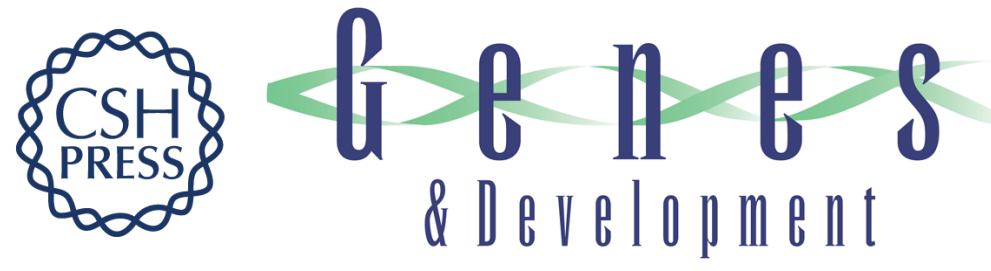

\section{Myxococcus xanthus, a gram-negative bacterium, contains a transmembrane protein serine/threonine kinase that blocks the secretion of beta-lactamase by phosphorylation.}

H Udo, J Munoz-Dorado, M Inouye, et al.

Genes Dev. 1995, 9:

Access the most recent version at doi:10.1101/gad.9.8.972

References This article cites 35 articles, 15 of which can be accessed free at: http://genesdev.cshlp.org/content/9/8/972.full.html\#ref-list-1

License

Email Alerting Service

Receive free email alerts when new articles cite this article - sign up in the box at the top right corner of the article or click here.

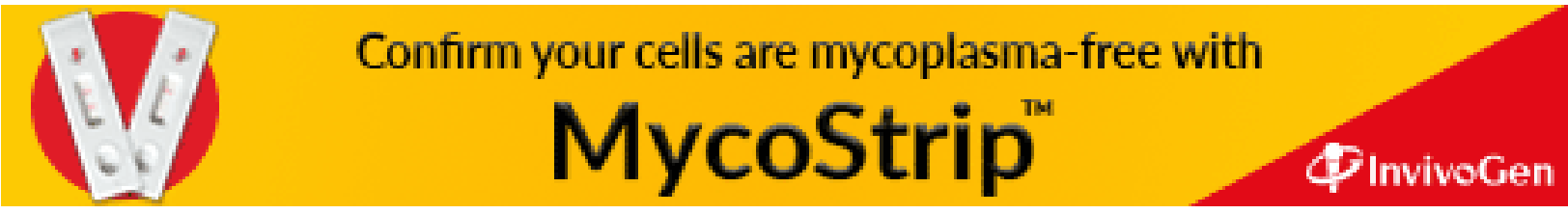

